\title{
SEPTICEMIA CAUSED BY Paracoccidioides brasiliensis (LUTZ, 1908) AS THE CAUSE OF DEATH OF AN AIDS PATIENT FROM SANTOS, SÃO PAULO STATE, BRAZIL - A NONENDEMIC AREA
}

\author{
Marcos Montani CASEIRO(1,2), Arnaldo ETZEL(2), Maria Cecilia B. SOARES(3) \& Sergio Olavo Pinto da COSTA(1)
}

\begin{abstract}
SUMMARY
The first case of Paracoccidioides brasiliensis in Santos (Brazil) leading to septicemia and death of an HIV-positive patient is reported here. The patient was a 34-year-old female that presented essential fever and was only diagnosed after death by positive blood culture. The authors underscore the atypical nature of the case, since the patient was a female at fertile age who was born and had always lived in Santos, which is a nonendemic area for this infection.
\end{abstract}

KEYWORDS: Paracoccidioidomycosis; Paracoccidioides brasiliensis; Aids.

\section{INTRODUCTION}

Paracoccidioidomycosis (PCM) is a systemic mycosis with geographic distribution limited to Latin America, where Brazil is the country with the highest number of cases ${ }^{10}$. This disease has heterogeneous distribution in Latin America with well-defined endemic areas ${ }^{7}$.

Acquired Immunodeficiency Syndrome (AIDS) is characterized by progressive immunodeficiency with decreased cellular adaptive response. This syndrome results in the development of various opportunist infections, including superficial and deep mycoses ${ }^{2,3}$. Candida albicans, Cryptococcus neoformans and Histoplasma capsulatum are the most frequently reported opportunistic microorganisms ${ }^{2,8}$.

AIDS-paracoccidioidomycosis coinfection is rarely reported. To date, there are only 84 cases in the related literature: 27 cases in a review published in $1995^{8} ; 52$ new cases in a review published in $2000^{2}$; two new cases in 2002 ${ }^{12}$; one case with eye and CNS infection in $2002^{6}$; one case with oral lesion ${ }^{1}$; and another with lung and pleural infection ${ }^{4}$.

The present study reports a case of a female patient who was born and lived in Santos, Brazil, and presented a clinical picture of acquired immunodeficiency caused by HIV. Although this patient had never traveled to an endemic area, she presented paracoccidioidomycosis diagnosed through blood culture. To our knowledge, this is the first case to be reported in Santos ${ }^{14}$.

\section{CASE REPORT}

A.L.P., 34-year-old, Caucasian, female, intravenous drug user, prostitute, was born and resident in Santos, Brazil. In February 1997, the patient was admitted to the Guilherme Álvaro Hospital of Santos and was presumptively diagnosed with herpes zoster ophthalmicus and pulmonary tuberculosis based on her clinical and radiographic signs and symptoms. The patient was then transferred to CRAIDS (AIDS Reference Center, Santos, Brazil) for outpatient treatment. At the first physical examination, the patient presented stomatitis, indicating oral candidiasis, with adenomegaly in the anterior and posterior cervical regions. The spleen was percussible but not palpable, and the liver edge was $2 \mathrm{~cm}$ below the right costal margin. Laboratory examination showed a CD4+ cell count of 41 cells $/ \mathrm{mm}^{3}$. Specific therapy with antiAIDS drug cocktail (3CT, d4T and EFV) was initiated due to the HIV/ AIDS infection and pulmonary tuberculosis - considering both the clinical picture and radiological aspect, but without bacteriological confirmation. The patient did not fully comply with the therapy, which was interrupted repeatedly. In July 2000, she sought help again with a clinical picture of continuous fever, asthenia and loss of $12 \mathrm{~kg}$ over the previous three months. At physical examination, the patient presented severe oropharyngeal candidiasis and generalized adenomegaly. The spleen was palpable one $\mathrm{cm}$ below the left costal margin; the liver edge was $3 \mathrm{~cm}$ below the right costal margin. No skin lesions were observed. Laboratory tests showed severe anemia and leukopenia. The patient presented a hemoglobin level of 6.9 and 1,100 leukocytes, which were not differentially diagnosed because of the leukopenia. After two $600 \mathrm{~mL}$ transfusions of blood cell concentrate, the patient presented, on September 14, 2000, a hemoglobin level of $7.1 \mathrm{~g} / \mathrm{dL}$ and 1,700 leukocytes, of which $65 \%$ were segmented and $11 \%$ were lymphocytes. She presented a CD 4 count of 6 cells $/ \mathrm{mm}^{3}$, a CD 8 count of 151 cells/ $\mathrm{mm}^{3}$ and a CD3 count of 158 cells $/ \mathrm{mm}^{3}$ on February 23, 2000 and viral load of 350,000 copies $/ \mathrm{mL}$. Chest x-ray revealed bilateral interstitial infiltrate. Once again, the patient was presumptively treated for tuberculosis and suspected pneumocystosis with a priming dose of

(1) Professor Pós-Graduação, Saúde Coletiva, UNISANTOS, Universidade Católica de Santos, SP, Brasil.

(2) Centro de Referência em Aids-Santos, SP, Brasil.

(3) Professor da Graduação e Mestranda em Saúde Coletiva, UNISANTOS, Santos, SP, Brasil.

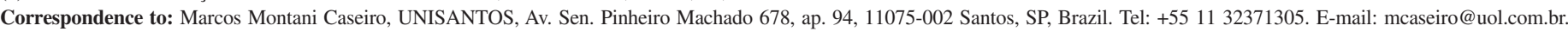




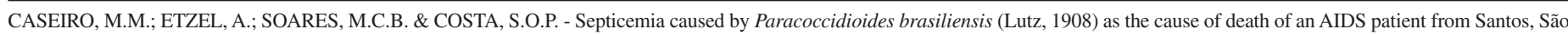
Paulo State, Brazil - a nonendemic area. Rev. Inst. Med. trop. S. Paulo, 47(4):209-211, 2005.

sulfamethoxazole + trimethoprim, $100 \mathrm{mg}$ per $\mathrm{kg}$ of body weight per day in four fractional doses for 21 days. Despite this therapy, her overall condition deteriorated dramatically. In addition to the therapy, she was also treated in a day hospital with resumption of antiretroviral therapy and several blood transfusions. Various blood cultures for bacteria and mycobacteria were performed and the results were negative. CD4 cell count was 6 cells $/ \mathrm{mm}^{3}$. In spite of outpatient clinic and day-hospital support, the patient's condition continued to worsen. New blood cultures were performed, including blood culture for fungi on transport medium (Negroni). Faced with her severe clinical picture, she was readmitted to hospital on October 28, 2000 and died on November 11, 2000. Blood was cultivated on BHIA medium, and after 35 days a slow-growing fungus in the yeast stage was isolated. This fungus was subsequently identified as Paracoccidioides brasiliensis ${ }^{14}$.

\section{DISCUSSION}

The Ministry of Health ${ }^{11}$ reports a total of 310,310 cases of AIDS in Brazil; candidiasis ranks first in number of related mycosis cases, while neurocryptococcosis ranks sixth. No reference has been made to paracoccidioidomycosis.

Among the cases described in the related literature, BERNARD \& DUARTE $^{2}$, in a comprehensive review carried out in 2000, reported high prevalence of HIV-PCM coinfection in patients with risk factors for HIV. Among the cases reported, 51\% were intravenous drug users, which indicates that IV drug use is a risk factor for PCM in both endemic and nonendemic areas when some of the individuals involved in needlesharing are from endemic regions. With regard to the clinical picture of HIV-PCM coinfection among the 56 patients studied, disseminated disease was observed in $77 \%$; enlarged lymph nodes, especially cervical, in $73 \%$; hepatomegaly in $43 \%$; splenomegaly in $29 \%$; osteoarticular lesion in $18 \%$; and enlarged intra-abdominal lymph nodes in $16 \%$. This distribution is in accordance with the acute form of the disease observed in HIV-negative patients ${ }^{2}$.

HADAD et al. ${ }^{9}$ (1992) analyzed a case of HIV-PCM coinfection with positive blood culture and observed that although this disease presented hematogenous dissemination, it was difficult to isolate the fungus from blood culture.

In the present case, there were non-specific pulmonary signs and symptoms with mild interstitial infiltrate, presumptively diagnosed and treated as pulmonary tuberculosis, although over 20 examinations and BAAR cultures had tested negative. It is noteworthy that, as of July, she presented essential fever, severe recurrent anemia and leukopenia. The patient had no cutaneous or oral mucosa lesions.

The authors point out the atypical nature of the case with regard to its epidemiology. We have observed and reported the first autochthonous case of paracoccidioidomycosis in the city of Santos, an urban area on the coast of Brazil, which is not related to endemic areas. The patient affirmed that she had always lived in Santos and had never traveled to endemic areas. However, she did report sharing needles with other drug users from different parts of São Paulo State. It is also noteworthy that the patient was female, since according to BERNARD \& DUARTE literature review ${ }^{2}$, the prevalence ratio of HIV-PCM coinfection between men and women was 3.3:1, which may be related to a possible protective effect from $\beta$-estradiol ${ }^{13}$.
The authors emphasize that it is likely that there have been other undiagnosed cases, as AIDS patients may present various diseases with a similar clinical course and which are more often described in the literature. The possibility of systemic fungal infections should be considered whenever there is a clinical picture of prolonged fever, lymphadenopathy and pulmonary interstitial infiltrate shown by chest $\mathrm{x}$-ray. In such cases, at least one blood culture for fungi should be performed.

\section{RESUMO}

Septicemia por Paracoccidioides brasilienses (Lutz, 1908) como causa de morte em paciente com síndrome da imunodeficiência adquirida (sida), procedente de área não endêmica, Santos, SP, Brasil

Relata-se o primeiro caso de Paracoccidioides brasiliensis, causando septicemia e morte em um paciente HIV positivo de 34 anos, do sexo feminino, natural e procedente de Santos, S.P.. A paciente apresentava-se com quadro febril inespecífico sendo que o diagnóstico só foi realizado pós morte da paciente através da positividade da hemocultura. Os autores chamam a atenção para a atipia do caso no que se refere ao fato de ser uma mulher em idade fértil e que nasceu e sempre residiu em Santos, área não endêmica para esta infecção.

\section{REFERENCES}

1. ALMEIDA, O. P.; JORGE Jr., J. \& SCULLY, C. - Paracoccidioidomycosis of the mouth: an emerging deep mycosis. Crit. Rev. oral Biol. Med., 14: 268-274, 2003.

2. BERNARD, G. \& DUARTE, A.J. - Paracoccidioidomycosis: a model for evaluation of the effects of human immunodeficiency virus infection on the natural history of endemic tropical diseases. Clin. infect. Dis., 31: 1032-1039, 2000.

3. BRUMMER, E.; CASTANEDA, E. \& RESTREPO, A. - Paracoccidioidomycosis: an update. Clin. Microbiol. Rev., 6: 89-117, 1993.

4. CORTI, M.; PALMIERI, O.; NEGRONI, R.; SOTO, I. \& VILLAFANE, M. F. Peripleuritis due to Paracoccidioides brasiliensis in a patient with AIDS. Medicina (B. Aires), 63: 417, 2003.

5. CORTI, M.; VILLAFANE, M.F.; NEGRONI, R. \& PALMIERI, O. - Disseminated paracoccidioidomycosis with pleuritis in an AIDS patient. Rev. Inst. Med. trop. S. Paulo, 46: 47-50, 2004.

6. FINAMOR, L.P.; MUCCIOLI, C.; MARTINS, M.C.; RIZZO, L.V. \& BELFORT Jr., R. Ocular and central nervous system paracoccidioidomycosis in a pregnant woman with acquired immunodeficiency syndrome. Amer. J. Ophthal., 134: 456-459, 2002.

7. FRANCO, M.; MONTENEGRO, M.R.; MENDES, R.F. et al. - Paracoccidioidomycosis: a recently proposed classification of its clinical forms. Rev. Soc. bras. Med. trop., 20: 129-132, 1987.

8. GOLDANI, L.Z. \& SUGAR, A.M. - Paracoccidioidomycosis and AIDS: an overview. Clin. infect. Dis., 21: 1275-1281, 1995.

9. HADAD, D.J.; PIERES, M.F.; PETRY, T.C. et al. - Paracoccidioides brasiliensis (Lutz, 1908) isolado por meio de hemocultura em um paciente portador de síndrome de imunodeficiência adquirida (SIDA). Rev. Inst. Med. trop. S. Paulo, 34: 565-567, 1992.

10. LACAZ, C.S. - Impacto das micoses no Brasil. Rev. Hosp. Clin. Fac. Med. S. Paulo, 40: 190-197, 1985. 


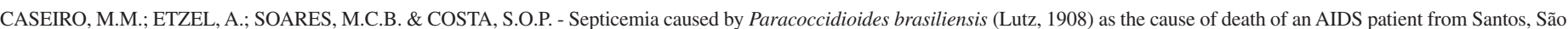
Paulo State, Brazil - a nonendemic area. Rev. Inst. Med. trop. S. Paulo, 47(4):209-211, 2005.

11. MINISTÉRIO DA SAÚDE - Dados preliminares até dezembro de 2003. Bol. Epidem. AIDS, XVII(1), 2003.

12. NOBRE, V.; BRAGA, E.; RAYES, A. et al. - Opportunistic infections in patients with AIDS admitted to an university hospital of the Southeast of Brazil. Rev. Inst. Med. trop. S. Paulo, 45: 69-74, 2003.

13. RESTREPO, A.; SALAZAR, M.E.; CANO, L.E. et al. - Estrogens inhibit mycelium-toyeast transformation in the fungus Paracoccidioides brasiliensis: implications for resistance of females to paracoccidioidomycosis. Infect. Immun., 46: 346-353, 1984
14. SOARES, M.C.B; CASEIRO, M.M.; AGELUNE, R.G.L. \& ZAMARIOLI, L.A. Septicemia by Paracoccidioides brasiliensis as death cause in patient with AIDS in the city of Santos, S.P.: case report. In: CONGRESSO BRASILEIRO DE MICROBIOLOGIA, 21., Foz do Iguaçu, 2001. Resumos. p. 86.

Received: 18 October 2004

Accepted: 16 May 2005 